\title{
UJI EFEKTIVITAS EKSTRAK SERAI (Cymbopogon citratus) TERHADAP PENYEMBUHAN LUKA SAYAT PADA MENCIT PUTIH
}

\author{
Maharuni Nurqadriasti Djuddawi ${ }^{1}$, Haryati ${ }^{2}$, Andi Noor Kholidha ${ }^{3}$
}

1) Mahasiswa Program Studi Pendidikan Dokter Konsentrasi Ilmu Keperawatan Fakultas Kedokteran Universitas Halu Oleo, Kendari, Sulawesi Tenggara

2) Program Studi Pendidikan Dokter, Konsentrasi Ilmu Keperawatan Fakultas Kedokteran, Universitas Halu Oleo, Kendari, Sulawesi Tenggara

3) Program Studi Pendidikan Dokter, Fakultas Kedokteran, Universitas Halu Oleo, Kendari, Sulawesi Tenggara

e-mail: haryati.aeta2017@gmail.com

\begin{abstract}
ABSTRAK
Luka adalah cedera pada bagian tubuh dimana kulit dan jaringan di bawahnya kehilangan kontinuitas jaringannya. Serai (Cymbopogon citratus) adalah salah satu tanaman yang sering digunakan sebagai obat yang dapat berfungsi sebagai antibakteri, antiinflamasi, dan antioksidan sehingga dapat mempengaruhi proses penyembuhan luka. Penelitian ini bertujuan untuk menilai efektivitas ekstrak serai (Cymbopogon citratus) terhadap penyembuhan luka sayat pada mencit putih. Penelitian ini merupakan penelitian true experimental dengan post-test only control group design. Penelitian ini menggunakan 25 ekor mencit jantan yang dibagi menjadi 5 kelompok, yaitu: kelompok eksrak serai $30 \%$, ekstrak serai $60 \%$, ekstrak serai $80 \%$, kontrol negatif (Aquades), dan kontrol positif (Bioplacenton). Pengelompokan subyek dilakukan secara random. Uji normalitas menggunakan uji Shapiro wilk menunjukkan nilai p pada masingmasing kelompok > 0,05, maka dapat disimpulkan bahwa distribusi data normal. Uji homogenitas dengan Levene's test diperoleh nilai $p=0,730(p>0,05)$, dengan demikian varian datanya homogen. Hasil analisis dengan One-Way Anova didapatkan nilai $p=0,881(p>0,05)$. Tidak ada perbedaan efektivitas ekstrak serai (Cymbopogon citratus) $30 \%, 60 \%$, dan $80 \%$ dibandingkan dengan kelompok kontrol negatif serta kontrol positif terhadap penyembuhan luka sayat pada mencit putih, namun penyembuhan luka pada kelompok ekstrak serai $60 \%$ terjadi lebih cepat dan telah tejadi penyembuhan luka secara total pada hari ke-14. Penyembuhan luka paling lambat terjadi pada kelompok ekstrak serai $80 \%$.
\end{abstract}

Kata Kunci: Ekstrak serai, penyembuhan luka, luka insisi, bioplasenton, aquades 


\begin{abstract}
Wound is injury to the part of the body where the skin and underlying tissues lose its tissue continuity. Lemongrass is one of the grass plants that often used as a medicine that can function as an antibacterial, anti-inflammatory, and antioxidant that can affect the wound healing process. This study aims to evaluate the effectiveness of lemongrass extract (Cymbopogon citratus) on wound healing in white mice.This research is true experimental research with a post-test only control group design. This research used 25 white mice divided into 5 groups: $30 \%$ lemongrass extract, 60\% lemongrass extract, $80 \%$ lemongrass extract, negative control (Aquades) and positive control (Bioplacenton). The grouping of subjects was carried out randomly. Normality test using the Shapiro Wilk test shows the $p$ value in each group $>0.05$, it can be concluded that the data distribution is normal. Levene's Test homogeneity test was obtained $p$ value $=0.730$ ( $p>0.05$ ), thus the data variant is homogeneous. The results of analysis with One-Way ANOVA test showed $p$ value $=0.881(p>0.05)$. There was no difference in the effectiveness of lemongrass extract (Cymbopogon citratus) 30\%, 60\%, and 80\% compared to negative control groups and positive control of wound healing in white mice. However, wound healing in the 60\% lemongrass extract group was faster and total wound healing had occurred on the 14th day. Wound healing is slowest in the $80 \%$ lemongrass extract group.
\end{abstract}

Keywords: Lemongrass extract, wound healing, incised wound, bioplasenton, aquades

\section{PENDAHULUAN}

Luka didefinisikan sebagai cedera pada bagian tubuh, dimana kulit dan jaringan di bawahnya kehilangan kontinuitas jaringannya. Luka dapat dialami semua orang tanpa memandang usia, ras maupun jenis kelamin. Segala aktivitas dalam kehidupan sehari-hari dapat menimbulkan risiko timbulnya luka pada tubuh [1]. Ada berbagai jenis luka, salah satu diantaranya yaitu luka sayat. Luka sayat (Vulnus scissum) merupakan luka yang disebabkan karena adanya trauma benda tajam [2].

Salah satu sediaan yang digunakan untuk mengobati luka adalah antimikroba. Sediaan antimikroba biasa digunakan untuk mengurangi risiko infeksi pada luka ringan. Salah satu antimikroba yang digunakan dalam penanganan luka adalah Povidone iodine. Povidone iodine merupakan sediaan yang paling umum digunakan di seluruh dunia karena aktivitas bakterisidal serta toksisitasnya yang rendah dan harganya relatif murah [3].Namun, belakangan ini dilaporkan bahwa Povidone iodine menimbulkan banyak efek samping diantarannya iododerma [4], luka bakar kimiawi [5], hingga reaksi anafilaksis [6].

Sediaan lain yang juga banyak digunakan untuk penyembuhan luka adalah Bioplacenton, yaitu gel yang mengandung ekstrak plasenta 10\% yang bekerja memicu pembentukan jaringan baru dan neomisin sulfat $0,5 \%$ yang membantu mencegah infeksi pada area luka [7]. Namun kandungan neomisin dapat menyebabkan reaksi hipersensitivitas. 
Penggunaan obat tradisional secara umum dinilai lebih aman dari pada penggunaan obat modern dengan catatan memenuhi kaidah dan aturan dalam penggunaanya. Hal ini disebabkan karena obat tradisional memiliki efek samping yang relatif lebih sedikit dari pada obat modern jika penggunannya dalam jumlah yang tepat dan rasional. Pengembangan obat atau agen alternatif untuk mengobati luka telah dilakukan selama bertahun-tahun. Saat ini, beberapa tanaman obat telah digunakan untuk mengobati luka [8]. Menurut survey dari WHO, sekitar 70-80\% dari populasi dunia menggunakan pengobatan non konvensional, terutama yang berasal dari herbal [9]. WHO juga mendukung upaya-upaya dalam peningkatan keamanan dan khasiat dari obat tradisional [10]. Faktor pendorong terjadinya peningkatan penggunaan obat herbal di negara maju adalah usia harapan hidup yang lebih panjang pada saat prevalensi penyakit kronik meningkat, adanya kegagalan penggunaan obat modern untuk penyakit tertentu seperti kanker serta semakin luasnya akses informasi mengenai obat herbal di seluruh dunia [10].

Salah satu tanaman yang sering digunakan sebagai obat adalah serai (Cymbopogon citratus). Tanaman ini berasal dari famili poaceae yang terdiri dari puluhan spesies. Dalam pengobatan tradisional, serai memiliki indikasi yang luas sebagai analgesik, antiseptik, antiemetik, antitusif, antirematik, antikonvulsan, serta pengobatan penyakit gastrointestinal dan saraf. Serai juga digunakan sebagai antibakteri, antiinflamasi, dan antioksidan sehingga dapat mempengaruhi proses penyembuhan luka [11].

Serai mengandung zat bioaktif seperti alkaloid, flavonoid, saponin, tanin, phenolic acid, dan terpenoid. Pada serai yang dikeringkan, zat bioaktif yang paling banyak terkandung adalah phenolic acid, flavonoid dan tanin yang berperan sebagai antioksidan yang berguna dalam penyembuhan luka [12].

Penelitian ini bertujuan untuk menilai efektivitas ekstrak serai (Cymbopogon citratus) terhadap penyembuhan luka sayat pada mencit putih.

\section{METODE PENELITIAN}

Penelitian ini merupakan penelitian true experimental yakni dilakukan pengujian efektivitas ekstrak serai terhadap penyembuhan luka sayat pada mencit putih. Penelitian ini menggunakan the post-test only control group design yang dilaksanakan pada 6-20 Maret 2018. Penelitian ini bertempat di Laboratorium Ruang Hewan Coba Fakultas Kedokteran Universitas Halu Oleo dan Laboratorium Farmakognosi dan Fitokimia STIKES Mandala Waluya Kendari.

Sampel dalam penelitian ini adalah mencit putih jantan berumur 2-3 bulan dengan berat badan 20-30 gr. Jumlah sampel ideal menurut hitungan rumus Federer adalah 5 ekor mencit putih atau lebih. Total jumlah 
mencit jantan dalam penelitian ini adalah 25 ekor. Kemudian sampel dibagi menjadi 5 kelompok, yaitu : kelompok ekstrak serai $30 \%$, ekstrak serai $60 \%$, ekstrak serai $80 \%$, kontrol negatif (Aquades), dan kontrol positif (Bioplacenton). Pengelompokan sampel dilakukan secara random dengan tolak ukur status fisiologis sampel yang sama.

Alat-alat yang digunakan pada penelitian ini adalah timbangan gram, scalpel, kandang, tempat minum mencit, cotton bud, jangka sorong, handphone, handscoon, masker, toples kaca, rotary vacum evaporator, spidol, pisau cukur, gelas ukur, blender, alat tulis, kapas, mikropipet, bengkok, perlak, alat maserasi, labu erlenmeyer, kertas saring/ corong, dan spoit. Bahan-bahan yang digunakan dalam penelitian ini adalah etanol 96\% sebagai pelarut, dietil eter sebagai anastesi hewan coba, kapas alkohol 70\% untuk desinfeksi hewan coba, serai, bioplacenton sebagai kontrol positif, aquades sebagai kontrol negatif dan sebagai pengencer konsentrasi ekstrak, serta air dan makanan hewan coba.

Tanaman serai yang digunakan dalam penelitian ini diperoleh dari Laboratorium Lapangan Fakultas Pertanian Universitas Halu Oleo. Serai yang digunakan adalah bagian batang yang memiliki warna hijau pada bagian atas dan warna putih pada bagian pangkal batang. Serai yang di pilih adalah serai yang masih segar dan memiliki bau khas serai. Serai yang masih segar dicuci dengan air mengalir. Setelah itu serai dipotong kecil-kecil $\pm 0,5 \mathrm{~cm}$ lalu dikeringkan dengan cara diangin-anginkan. Serai yang sudah kering kemudian dihaluskan dengan menggunakan blender. Ekstraksi serai menggunakan metode maserasi. Proses maserasi serbuk serai pada penelitian ini dilakukan selama $3 \times 24$ jam. Hasil dari proses maserasi sampel (maserat) kemudian dipisahkan dari ampas dengan menggunakan corong dan kertas saring lalu diuapkan dengan menggunakan alat Rotary Vacum Evaporator (rotavapor). Variasi kadar ekstrak dibuat dengan pengenceran menggunakan aquades kemudian dibuat kadar ekstrak serai dengan konsentrasi masing-masing 30\%, 60\%, dan $80 \%$.

Mencit yang akan digunakan terlebih dahulu diadaptasikan selama 1 minggu di laboratorium ruang hewan coba. Selanjutnya, rambut pada daerah punggung mencit dicukur dan dilakukan pembuatan luka sayat sepanjang $1 \mathrm{~cm}$ dan kedalaman $1 \mathrm{~mm}$ dengan cara kulit diregangkan dengan jari telunjuk dan ibu jari tangan kiri bertindak sebagai peregang dan penekan, dengan posisi mencit tengkurap. Pemberian perlakuan pada setiap kelompok sampel dilakukan dengan frekuensi dua kali sehari yaitu pada pagi hari pukul 09.00 WITA dan sore hari pukul 15.00 WITA selama 14 hari berturut-turut.

Pengamatan dilakukan pada semua kelompok dengan cara makroskopik yaitu 
menggunakan jangka sorong untuk mengukur panjang luka yang dilakukan setiap 2 hari sekali. Penyembuhan luka sayat ditandai dengan tidak terdapatnya tanda-tanda infeksi, perubahan panjang luka atau terjadi penutupan luka secara sempurna. Ketika mencit telah selesai digunakan dalam penelitian, maka selanjutnya dilakukan pemusnahan mencit dengan cara dislokasi leher.

\section{HASIL DAN PEMBAHASAN}

Rata-rata panjang luka (cm) pada kelompok perlakuan ekstrak serai 30\%, 60\%, $80 \%$, kelompok kontrol negatif (Aquades), dan kelompok kontrol positif (Bioplacenton) yang diukur pada hari pertama sampai hari terakhir (hari ke-14) terlihat pada tabel 1.

Table 1. Rata-rata Panjang Luka (cm)

\begin{tabular}{cccccc}
\hline Hari Ke- & ES 30\% & ES 60\% & ES 80\% & Kontrol (-) & Kontrol $(+)$ \\
\hline 0 & 1 & 1 & 1 & 1 & 1 \\
2 & 0,74 & 0,78 & 1 & 0,96 & 0,88 \\
4 & 0,62 & 0,52 & 0,82 & 0,84 & 0,74 \\
6 & 0,50 & 0,46 & 0,72 & 0,66 & 0,62 \\
8 & 0,36 & 0,12 & 0,54 & 0,28 & 0,42 \\
10 & 0,18 & 0,08 & 0,34 & 0,08 & 0,22 \\
12 & 0,08 & 0,06 & 0,10 & 0,02 & 0,08 \\
14 & 0,04 & 0 & 0,06 & 0 & 0,04 \\
Rata-rata & 0,44 & 0,38 & 0,57 & 0,48 & 0,50 \\
\hline
\end{tabular}

Pengamatan penyembuhan luka ekstrak serai $60 \%$ dan kontrol negatif dilakukan setiap 2 hari sekali selama 14 hari (Aquades) terjadi penyembuhan luka secara terhadap 5 kelompok perlakuan yaitu a) total pada hari ke-14. Sedangkan pada ekstrak serai $30 \%$, b) ekstrak serai $60 \%$, c) kelompok ekstrak serai $30 \%$, $80 \%$, dan ekstrak serai $80 \%$, d) kontrol negatif kontrol positif (Bioplacenton) belum terjadi (Aquades), dan e) kontrol positif penyembuhan luka secara total pada hari ke(Bioplacenton). Pada kelompok perlakuan 14. Berdasarkan rata-rata panjang luka pada 
masing-masing kelompok dapat disimpulkan bahwa penyembuhan luka pada kelompok ekstrak serai $60 \%$ terjadi lebih cepat yang disusul oleh kelompok kontrol negatif (Aquades). Penyembuhan luka paling lambat terjadi pada kelompok ekstrak serai $80 \%$.

Uji normalitas menggunakan uji Shapiro wilk, diperoleh nilai $\mathrm{p}$ pada masingmasing kelompok lebih dari 0,05, maka disimpulkan bahwa distribusi data normal. Selanjutnya uji homogenitas pada penelitian ini menunjukkan nilai $p=0,730 \quad(p>0,05)$, dengan demikian varian datanya adalah homogen. Hasil analisis One-Way Anova diperoleh nilai $p=0,881 \quad(p>0,05)$, sehingga disimpulkan bahwa tidak ada perbedaan efektivitas ekstrak serai (Cymbopogon citratus) $30 \%$, 60\%, dan $80 \%$ dibandingkan dengan kelompok kontrol negatif serta kontrol positif terhadap penyembuhan luka sayat pada mencit putih.

Fase penyembuhan luka terdiri atas fase inflamasi, fase proliferasi, dan fase maturasi (Black \& Hawks, 2009). Rata-rata fase penyembuhan luka pada hari pertama sampai hari ke-4 pada kelompok yang diberikan ekstrak serai 30\% dan 60\% terjadi fase inflamasi yang menunjukkan pengurangan panjang luka yang lebih cepat dibandingkan kelompok ekstrak serai $80 \%$, kontrol negatif (Aquades), dan kontrol positif (Bioplacenton) yang mengalami fase inflamasi sampai hari ke-6. Hal ini terjadi karena kandungan zat bioaktif dari serai berupa flavonoid yang dapat menghentikan pendarahan pada luka serta berperan sebagai zat antiiflamasi yang akan mempengaruhi produksi sel-sel inflamasi dalam fase inflamasi penyembuhan luka. Tanin sebagai astrigen dapat berpengaruh terhadap berkurangnya permeabilitas mukosa dan ikatan antar mukosa menjadi kuat sehingga mencegah iritan dan secara tidak langsung tanin berpengaruh terhadap permeabilitas mukosa dan dinding bakteri sehingga bakteri mengkerut dan mati. Kandungan Phenolic acid dalam serai berperan dalam mencegah kerusakan sel akibat radikal bebas sehingga mencegah proses inflamasi dan peradangan [13].

Pada penelitian ini didapatkan hasil bahwa ekstrak serai $60 \%$ efektif terhadap penyembuhan luka sayat pada mencit putih dibandingkan dengan ekstrak serai 30\% dan $80 \%$. Hal ini disebabkan karena pada konsentrasi 30\%, senyawa metabolit sekunder pada ekstrak serai sudah memiliki pengaruh terhadap luka, tetapi pada konsentrasi kecil hanya bersifat menghambat mikroorganisme sehingga kurang efektif dalam penyembuhan luka. Hal ini sesuai dengan pendapat Miranti (2013)[14] yang menyatakan bahwa apabila antibakteri digunakan pada konsentrasi kecil hanya bersifat menghambat (bakteriostatik), tetapi 
apabila digunakan pada konsentrasi tinggi akan bersifat membunuh mikroorganisme. Sedangkan proses penyembuhan luka pada ekstrak serai $80 \%$ yang lebih lambat dibandingkan ekstrak serai $60 \%$ disebabkan karena kepekatan dan kemampuan difusi bahan yang berbeda akibat perbedaan konsentrasi. Referensi [15] menyatakan bahwa kemampuan difusi yang rendah disebabkan esktrak yang terlalu pekat karena konsentrasi yang terlalu tinggi. Hal ini menyebabkan ekstrak sulit berdifusi maksimal ke dalam medium yang mengandung inokulum.

Pada konsentrasi yang lebih tinggi dapat terjadi kejenuhan sehingga menyebabkan senyawa-senyawa aktif yang terkandung di dalam ekstrak tidak terlarut sempurna. Hal ini dikarenakan pada konsentrasi yang tinggi terjadi saling ikat antar molekul yang terkandung dalam ekstrak sehingga terbentuk molekul yang berukuran lebih besar. Semakin tinggi konsentrasi maka pembentukan senyawa berukuran lebih besar menjadi lebih banyak sehingga menyebabkan senyawa-senyawa aktif yang terkandung dalam ekstrak berukuran lebih besar dari sebelumnya. Molekul berukuran besar ini tidak mampu menembus pori-pori dan menyebabkan tidak terjadi kontak langsung antara senyawa aktif dengan membran.
Berbeda dengan penelitian referensi [12] terhadap penyembuhan luka mukosa labial mencit dengan menggunakan ekstrak serai $100 \%$, 50\%, dan $25 \%$, didapatkan bahwa ekstrak serai $100 \%$ dan $50 \%$ dapat mempercepat penyembuhan luka mukosa labial mencit dilihat dari panjang luka. Semakin tinggi konsentrasi ekstrak, semakin cepat penyembuhan lukanya yang mungkin disebabkan oleh kandungan zat aktif yang lebih banyak pada ekstrak dengan konsentrasi yang lebih tinggi. Namun, tidak ada perbedaan bermakna antara konsentrasi ekstrak serai $100 \%$, 50\%, dan 25\%

Faktor lain yang juga dapat mempengaruhi hasil penelitian ini adalah jumlah sampel yang digunakan lebih sedikit dari penelitian sebelumnya yang menggunakan sampel sebanyak 30 ekor mencit sedangkan pada penelitian ini sebanyak 25 ekor mencit. Banyaknya jumlah sampel yang digunakan akan mempengaruhi suatu penelitian karena semakin banyak jumlah sampel yang digunakan maka akan semakin kecil peluang kesalahan generalisasi.

Kemungkinan faktor dari dalam tubuh mencit yang juga dapat mempengaruhi hasil yaitu stres sebagai faktor yang tidak bisa diabaikan karena dapat mempengaruhi proses penyembuhan luka. Referensi [16] mengatakan bahwa stres dapat memicu 
peningkatan kortisol yang berdampak terhadap supresi imunitas seluler sehingga dapat memperlambat penyembuhan luka.

\section{KESIMPULAN}

Berdasarkan hasil penelitian yang telah dilakukan, maka dapat disimpulkan bahwa tidak terdapat perbedaan efektivitas ekstrak serai (Cymbopogon citratus) 30\%, $60 \%$, dan $80 \%$ dibandingkan dengan kelompok kontrol negatif serta kelompok kontrol positif terhadap penyembuhan luka sayat pada mencit putih, namun penyembuhan luka pada kelompok ekstrak serai $60 \%$ terjadi lebih cepat dan telah tejadi penyembuhan luka secara total pada hari ke14. Penyembuhan luka paling lambat terjadi pada kelompok ekstrak serai $80 \%$.

\section{DAFTAR PUSTAKA}

1. Franz, M.G., Robson, M.C., Steed, D.L., Barbul, A., Brem, H., Cooper, D.M. Guidelines To Aid Healing Of Acute Wounds By Decreasing Impediments Of Healing. Wound Repair Regen. 2008; 16(6): 723-48.

2. Orsted, H.L., Keast, D.K., Kuhnke, J., Armstrong, P. Best Practice

Recommendations For The Prevention And Management Of Open Surgical Wounds. Wound Care Canada. $2010 ; 8(1)$.
3. Sammartino, G., Tia, M., Tete, S., Perillo, L., Trosino, O. Adverse Reaction To Irrigation With Povidone-lodine After Deepimpacted, Lower Third Molar Extraction. J Biol Regul Homeost Agents. 2012;26(1):145-9.

4. Aliagaoglu, C., Turan, H., Uslu, E., Albayrak, H., Yazici, S., Kaya, E. lododerma Following Topical Povidonelodine Application. Cutan Ocul Toxicol. 2013; 32(4): 339-40.

5. Rees, A., Sherrod, Q., Young, L. Chemical Burn From Povidone-lodine: Case And Review. J Drugs Dermatol. 2011; 10(4): 414-7.

6. Gray, P.E., Katelaris, C.H., Lipson, D. Recurrent Anaphylaxis Caused By Topical Povidoneiodine (Betadine). J Paediatr Child Heal. 2013;49(506-7).

7. Kalbamed. 2013. Bioplacenton. Kalbe Medikal Portal. http://www.kalbamed.com/Products/Drug s/Branded/tabib/245/ID/5699/Bioplacento n.aspx.

8. Meir, K., dan Nanney, L. Emerging New Drugs For Wound Repair. Expert Opin Emerg Drugs. 2006;11(2) :23-37.

9. Verma, P.W., Sultana, M., Raina, R. 2012. Quantitative Analysis Of Total Phenolic, Flavonoids And Tannin Contents In Acetone And N-Hexane Extracts Of Ageratum Conyzoides. 
International Journal of Chem Tech Research. 4(3): 996-9.

10. Purwanto, B. 2013. Herbal dan Keperawa tan Komplementer (Teori, Praktik, Hukum dalam Asuhan Keperawatan). Nuha Medika. Jakarta.

11. Figueirinhaa, A., António, P., José, J.P.A., Celestino, S.B., dan Maria,T.B. Cymbopogon citratus leaves: Characterization of flavonoids by HPLCPDA-ESI/MS and an approach to their potential as a source of bioactive polyphenols. Food Chemistry 2008; 110(3): 718-728.

12. Hairi, M. Pengaruh ekstrak sereh (Cymbopogon citrates) Terhadap Panjang Luka Mukosa Labial Mencit Secara Klinis. Dentiono Jurnal Kedokteran Gigi. 2016.

13. Wahyuni, S. Pengaruh Pemberian Salep Fitoplankton Chlorell vulgaris Terhadap Penyembuhan Luka Sayat (Incisi)Pada Mencit (Mus musculus albinus).Skripsi. Universitas Hasanuddin.

14. Miranti, M., Prasetyorini dan Suwary, C. Perbandingan Aktivitas Antibakteri EkstraK Etanol 30\% dan 90\% Kelopak
Bunga Rosella (Hibiscus sabdariffa L.) Terhadap Bakteri Staphylococcus aureus. Scientific Journal. 2013.13(1): 3541. Universitas Pakuan.

15. Fitriani, A. 2014. Aktivitas Alkaloid Ageratum conyzoides $L$. Terhadap

Pertumbuhan Bakteri Stapylococcus aureus secara In Vitro. Jurusan Pendidikan Biologi, FPMIPA, Universitas Pendidikan Indonesia.

16. Yusuf, A., Alit, N.K., Nurfianti, A. 2017. Stres Memperlambat Penyembuhan Luka Paska Seksio Sesarea (Stress Prolongs Wound Healing Post Cesarean Section). Jurnal Ners 2 (2), 103-106. Universitas Airlangga. 